In memoriam

Allan Gotthelf

(30 December 1942-30 August 2013)^

\author{
James G. Lennox \\ University of Pittsburgh \\ jglennox@pitt.edu
}

Allan Gotthelf passed away on August 30, 2013 in his apartment in Philadelphia under the care of close friends, finally succumbing to the cancer that he had battled successfully for many years. He has left behind a lasting legacy of distinguished scholarship on Aristotle's philosophy and science; but more than that, Allan was able, through his infectious enthusiasm, spirit of cooperation, and formidable organizational skills, to reshape the field of Aristotelian studies fundamentally. Not only through his scholarly publications but through his prodigious organization of workshops, conferences, summer institutes, and a truly astounding network of correspondence, which only became more astounding with the advent of the Internet, Allan was able to involve an ever expanding number of scholars in a systematic study of Aristotle's biological writings, encouraging us to consider the Generation of Animals, Parts of Animals and History of Animals as much a part of our scholarly diet as the Organon, Metaphysics, or Nicomachean Ethics. Indeed, he encouraged us to think of these investigations as sources of insight into these philosophical works and not merely as documents in the history of biology.

Born in Brooklyn on December 30, 1942, Allan Gotthelf came of age during the heyday of the Brooklyn Dodgers, attending games at Ebbets Field as a young boy shortly after Jackie Robinson had joined the team, an event that left a lasting impression. He attended the highly acclaimed Stuyvesant

* For Allan Gotthelf's curriculum vitae and list of publications, please go to http:// wuw.ircps.org/directory/allan-s-gotthelf

(C) 2013 Institute for Research in Classical Philosophy and Science All rights reserved
ISSN 1549-4497 (online) ISSN 1549-4470 (print) 
High School, where he developed a passion for mathematics and science, and, in 1959, he enrolled in Brooklyn College intent on pursuing a joint degree in mathematics and physics. His intellectual focus was redirected toward philosophy during the summer of 1961 as a consequence of reading Atlas Shrugged, the epic novel by American novelist and philosopher Ayn Rand that stressed the fundamental importance of philosophy in the lives of individuals and cultures.

He graduated in 1963 with a major in mathematics and a minor in philosophy and, after earning an MA in mathematics at Penn State, entered the graduate program in philosophy at Columbia University. Again under the influence of Ayn Rand, who had a profound admiration for Aristotle, Gotthelf eventually decided to write his dissertation on 'Aristotle's Conception of Final Causality', which he defended before a committee consisting of James Walsh, Paul Kristeller, and John Herman Randall Jr. He was awarded his PhD in 1975 and, a year later, an article based on his dissertation that presented its deeply original thesis-that for Aristotle, final causality, the idea that goals were somehow responsible for processes directed toward their realization, was rooted in an irreducible potential for form-was awarded the dissertation essay prize of the Review of Metaphysics and was published in volume 30 of that journal. This was to be the first of a series of six papers dealing with different aspects of Aristotle's commitment to teleology, which span the entirety of his career and now comprise the first six chapters in his collected papers, Teleology, First Principles, and Scientific Method in Aristotle's Biology (2012).

It is quite unusual for a first publication to have the sort of impact that 'Aristotle's Conception of Final Causality' did but it was not an accident. In the interests of having scholars actively engage with the interpretation that he was defending, Allan compiled a list of people in the fields of ancient philosophy, philosophy of science, and even biology who he had reason to believe would find the argument of interest and sent offprints, typically with introductory notes, to everyone on that list. This act of engagement had the desired impact: it was not long before anyone who took up the topic of Aristotle's teleology had to contend with Allan's thesis and argument, that Aristotle's teleology was a scientific claim about the causality of biological processes and rooted in his metaphysics of (formal and material) natures and (active and passive) potentials. Teleology thus implied no quasi-conscious agents, demiurgic designers, or future states affecting the past; and yet it 
was a distinctive form of causation not reducible to the causal interactions of the materials involved in those processes. Through revieus of their work, and occasional review articles like his 'Understanding Aristotle's Teleology' (1997), Allan engaged in an on-going discussion with those scholars who had challenged his vieus-on-going until his last days. In an email that he sent to me less than four months before his death, Allan expressed regrets that his health would likely not permit him to attend the Princeton Classical Philosophy Colloquium in 2013, 'Necessity and Teleology in Aristotle's Natural Philosophy'. He especially regretted having to be absent because it would have provided him an opportunity to talk to a number of younger scholars who had expressed reservations about his interpretation.

In 1979, three years after the publication of this ground-breaking article, he was awarded a prestigious Junior Fellowship at the Center for Hellenic Studies in Washington, DC and it was during his year at the Center that he began to develop a proposal for a collection of essays on Aristotle's biology. Over the next 20 years, Allan played a central role in organizing conferences, workshops, and summer institutes that encouraged scholars of Aristotle's philosophy to integrate the study of his biological works into their research. It was the first of these, a 10-day conference entitled 'Philosophical Issues in Aristotle's Biology', that would serve as the basis for a wide-ranging collection of papers highlighting Aristotle's biological writings as a valuable source for exploring central themes in Aristotle's philosophy. Organized in collaboration with David Balme, it took place at Williams College in Williamstown, MA during the summer of 1983 . The resulting eponymous volume, which I was privileged to co-edit, is widely credited with moving Aristotle's animal investigations into a central place in Aristotle studies.

Allan was thrilled to collaborate with David Balme on this event. Balme's translation and commentary of sections of the Parts and Generation of Animals in the Clarendon Aristotle Series (1972) had been a revelation to Allan. They became friends during Balme's visit to the Institute for Advanced Study in Princeton in 1976 and interacted constantly until Balme's untimely death in 1989. Allan took great pleasure in organizing and editing the Festschrift in Balme's honor, Aristotle on Nature and Living Things (1985); and in 1986, Allan was awarded a three year NSF grant to carry out collaborative research on the History of Animals with Balme, which turned out to be the last three years of Balme's life. After Balme's death, Allan devoted a significant portion 
of the remainder of his life to seeing through to publication Balme's draft of the third volume of the Loeb edition of the History of Animals 7-10 as well as his editio maior of the Historia animalium, a draft of which Balme had completed for the series, Cambridge Classical Texts and Commentaries. Thanks to Allan's efforts, the Loeb volume appeared in 1991 and the first volume of the editio maior (consisting of an extensive introduction, text, apparatus, and index) in 2002. Allan was roughly halfway through preparing the second volume, the commentary, when ill health forced him to put work on it aside.

There were to be many other conference collaborations on related themes-with Sir Geoffrey Lloyd (1985, 'Aristotle's Philosophy of Biology', King's College, Cambridge), Pierre Pellegrin and Daniel Devereux (1987, 'Joint CNRS/NSF Seminar on Interconnections of Biology, Scientific Method and Metaphysics in the Scientific and Philosophical Writings of Aristotle', Oléron), John Cooper and Michael Frede (1988, 'NEH Summer Institute on Aristotle's Metaphysics, Biology and Ethics', University of New Hampshire), and Wolfgang Kullmann and Sabine Föllinger (1995, 'Symposiums über 'Aristoteles' Biologie", Werner-Reimers-Stiftung, Bad Homburg). Through his central role in conceiving and orchestrating these events, Allan earned a reputation as an extraordinary organizer and the Oléron and Bad Homburg conferences led to the publication of important collections of essays that further contributed to moving Aristotle's biological writings to the center of Aristotle scholarship.

Allan was without doubt a major force behind the organization of conferences during this period but he was publishing ground-breaking essays as well: 'Notes towards a Study of Substance and Essence in Aristotle's Parts of Animals II-IV' (1985), 'First Principles in Aristotle's Parts of Animals' (1987), 'Historiae I: Plantarum et Animalium' (1988), 'The Elephant's Nose: Further Reflections on the Axiomatic Structure of Biological Explanation in Aristotle' (1997), and 'Division and Explanation in Aristotle's Parts of Animals' (1997). All of these essays were aimed at deepening our understanding of the way in which Aristotle's metaphysics and theory of knowledge informed the logical and explanatory structure of his study of animals and, conversely, how a more detailed and systematic study of these biological investigations could deepen our understanding of his philosophy.

In the late 1990s, Allan was diagnosed with cancer and this led him to take early retirement from The College of New Jersey in 2002, where he had 
served as department chair from 1988 to 1997 and had helped develop a Minor in Classical Studies. In his honor, the College created the Gotthelf Prize to be awarded annually to an outstanding graduating student in Classical Studies, selected by the faculty of that program.

That award spotlights an equally important facet of Allan's professional life, his love of teaching. Allan discovered that he had a gift for teaching early on. While still in graduate school, he taught an introduction to philosophy at the Pratt Institute in Brooklyn and for the next three years-while still in graduate school-was a full time philosophy instructor at Wesleyan University. By the time he had been awarded his PhD from Columbia, he had been Assistant Professor of Philosophy at Trenton State College (now The College of New Jersey) for six years and had already been awarded tenure. Having co-taught with Allan on a number of occasions, I was able to experience at first hand his pedagogical talents. His natural warmth and benevolence helped him to forge personal, one-on-one relationships with his students. He conveyed his passion for philosophy and the role of clear and rigorous philosophical thought in the achievement of one's goals in memorable ways, often through the use of humor. Whatever subject was being taught, his classes were workshops in philosophical method and the value of philosophy. Knowing the importance of good teaching, Allan looked for ways to pass on the skills that he had acquired. From 1982-1990, he and Michael Hooker conducted APA Eastern Division sponsored weekend teaching workshops.

Though there was no graduate program in philosophy at his home institution, throughout his career, Allan sought out opportunities to teach graduate seminars often in collaboration with others: with John Ackrill at Oxford in Trinity Term 1984, at Georgetown University in 1985, with David Charles and me at Oxford in Trinity Term 1994, and at Tokyo Metropolitan University in the Summer of 1994.

After his early retirement from TCNJ, Allan spent a term as visiting professor at the University of Texas, Austin and, thanks to an Anthem Fellouship for the Study of Objectivism, subsequently joined me in the department of History and Philosophy of Science at the University of Pittsburgh. Shortly after his arrival, in 2004, Robert Bolton and I organized a conference, 'Being, Nature and Life in Aristotle', to honor Allan's contributions to the study of classical philosophy and science. The papers presented at that event, along with a number of others by people who had wanted to attend but could not, 
were published in a Festschrift entitled Being, Nature and Life in Aristotle: Essays in Honor of Allan Gotthelf, edited by Bolton and me and published by Cambridge in 2010.

One of his greatest pleasures when he joined the faculty of the University of Pittsburgh in 2003 was being able to teach and direct graduate students. Though his Anthem Fellowship did not require it, while at Pittsburgh he taught, or co-taught with me, four graduate seminars and served with me on two doctoral committees. He was also a constant presence at the reading groups of the Program in Classics, Philosophy, and Ancient Science and sat in on a number of his colleagues' graduate seminars.

Unfortunately, in 2011, Allan's status as visiting professor at Pittsburgh ran up against a bureaucratic 'statute of limitations' and the Anthem Foundation had to search for another home for his Fellowship. The Department of Philosophy at Rutgers University happily complied and, in 2012, Allan was appointed there as the Anthem Foundation Distinguished Fellow for Research and Teaching in Philosophy. He taught an advanced undergraduate class on Aristotle during his first year there and was planning on co-teaching a graduate seminar with Robert Bolton in the Fall Term of 2013.

As I noted earlier, Allan was first oriented toward philosophy and Aristotle by his early encounter with Ayn Rand's philosophy of Objectivism. Rand's admiration for Aristotle was clear to an attentive reader of Atlas Shrugged but far more obvious in the lectures and non-fiction essays that she began to publish in the early 1960s. Throughout his career, Allan devoted considerable energy to encouraging the study of Objectivism among academic philosophers. He was a founding member and, as its secretary, the guiding spirit of the Ayn Rand Society of the APA, which was founded in 1988. His vision for the yearly meetings of the Society was to select a topic of central importance to Objectivism on which scholars sympathetic to Rand's approach would engage prominent specialists-the goal being to familiarize both the audience and the invited specialist with the distinctive approach of Objectivism to the topic at hand.

His Anthem Foundation Fellowship was designed so that he could devote part of his research to promoting the scholarly study of Objectivism. In 2000, Allan published On Ayn Rand as part of the Wadsworth Philosophers Series; and soon after he joined me in Pittsburgh, we contracted with the University of Pittsburgh Press to publish a series entitled 'Ayn Rand Society 
Philosophical Studies', each volume to be based on papers presented at the Society meetings over the years. Volume 1 (Metaethics, Egoism and Virtue: Studies in Ayn Rand's Normative Theory) was published in 2011 and volume 2 (Concepts and Their Role in Knowledge: Reflections on Objectivist Epistemology) appeared in 2013, just a few months before Allan passed away.

With the same goal in view, during his years in Pittsburgh, he co-organized a series of workshops that brought philosophers trained in the Analytic tradition together with philosophers sympathetic to Objectivism on themes such as 'Concepts and Objectivity', 'Normativity and Justification in Epistemology and Ethics', and 'Perception, Consciousness and Reference'. Three publications with the same objective were in the planning stages when Allan passed away: Ayn Rand: A Companion to Her Works and Thought, co-edited with Gregory Salmieri for Blackwell Companions to Philosophy series; Ayn Rand as Aristotelian, volume 3 in the Ayn Rand Society Philosophical Studies series; and Concepts, Induction and the Growth of Scientific Knowledge, to be co-edited with Richard Burian. This last was based on a conference that reflected Allan's deepening interest during his years in Pittsburgh in the relationship between concept formation and induction, a topic of importance both for Objectivism and for Aristotle.

As if the projects that I have just recounted were not enough, during these years in Pittsburgh Allan also organized or co-organized a series of six workshops on Aristotle's Generation of Animals (which helped inspire chapters 4 and 5 of his collected papers of 2012); a series of workshops on 'Discovery and Justification in Aristotle'; and (with Robert Mayhew) a workshop on the Aristotelian Problemata. He also began planning with Armand LeRoi, a developmental biologist and producer of the BBC documentary 'Aristotle's Lagoon', a Penguin Classics volume of selections from Aristotle's biological works, a project which will hopefully be brought to completion by LeRoi and myself.

Having read a review of Allan's life as a scholar and teacher, a reader might be left with the impression that Allan's professional life was his life. Those who knew Allan, however, were well aware of his many passions outside of philosophy, though he was always happy to explain how each of them related to his philosophical sense of life. From his childhood encounter with Jackie Robinson breaking the color barrier in baseball, Allan developed a lifelong interest in the history of the Negro Leagues during the time when baseball was a segregated sport. While living in the Philadelphia area, he became an 
avid fan of the Flyers hockey team and, when he moved to Pittsburgh, he became equally passionate about the Penguins. He had a deep love for Frank Lloyd Wright's architecture and during his life even managed to arrange to live briefly in a number of homes designed by Wright. He was an avid film buff and had deep love for many genre of music, especially romantic piano and operetta. Allan approached each of these subjects as he did everything-with an intense desire both to experience and to understand. He took great pleasure in sharing these, and other, passions with his close friends.

Among these non-academic pleasures, there was always a special place in Allan's heart for a small Inn built in 1810 at the base of Mt Snowdon in Northern Wales named Pen-y-Guryd, where Sir Edmond Hillary, Tenzing Norgay, and their team resided while training for the first successful ascent of Mt Everest in 1953. Part of its charm lies in the fact that it is filled with rare, historic memorabilia related to that event and that team members had reunions there every 10 years. From his first visit in 1984 as a fellow at Clare Hall, Cambridge and Wolfson College, Oxford, Allan loved the vivid presence of history in the UK and his visits to Pen-y-Guryd were among his greatest pleasures. Typically, Allan became close friends of the innkeepers and on most of his many trips to Great Britain he would find time to return to Pen-y-Guryd.

It will come as no surprise to readers who knew Allan that he spent his remaining time, after it became clear that he had only months to live, focused on insuring that the projects which he was then working on would be carried through to completion. As he faced the imminent end of his life, Allan remained focused on the future and on the achievement of values of importance to him.

Allan Gotthelf is survived by Ronald and Cassandra Love and their sons Zach and Ian Barber, whom Allan regarded as family, and by his sister Joan Gotthelf Price. He will be remembered fondly by his many friends, colleagues, and students.

\section{A Personal Note}

Because my unique relationship with Allan no doubt colors this remembrance of his life, I will here briefly recount our 42 years of continuous collaboration and friendship. We first met in 1971, during my last year as an undergraduate philosophy major at York University in Toronto. We were in- 
troduced by a professor at York who was close friends with Allan and knew of our shared interest in both Aristotle and Ayn Rand. After our first meeting, Allan agreed to read and discuss with me my undergraduate honors thesis on Aristotle's De anima. He encouraged me to consider a career in philosophy and served as an unofficial advisor all through my time in graduate school at the University of Toronto. I had a strong interest in the philosophy of biology as well as in ancient philosophy and was able to combine those interests by writing a dissertation on the relationship between the concepts of matter, form, potentiality, and actuality in Aristotle's Metaphysics and the use of those concepts in the biological works. Thus, early on, Allan and I became jointly engaged in the project of trying to understand the ways in which a study of the biological works could inform a study of Aristotle's philosophy. During a visit to the Princeton Classical Philosophy Colloquium in 1976 (on Aristotle's biology, with lectures by Montgomery Furth, Marjorie Grene, and David Balme), Allan introduced me to David Balme, at the time a Fellow at the Institute for Advanced Study. With encouragement from Allan, I recruited Balme to be the external reader of my dissertation. From that point on, Allan and I corresponded constantly, commented on drafts of each others' papers, and often attended the same conferences. In 1982, we spent a good part of the summer together as participants in an NEH Summer Seminar on the Philosophy of Biology at Cornell University organized by Dick Burian and Marjorie Grene-and of course the following summer was the Williamstown conference organized by Allan, mentioned above.

The following year, I was a Junior Fellow at the Center for Hellenic Studies, where Allan and I read through the entirety of the Historia animalium, meeting regularly all through the Fall term to discuss key passages in each book. It was at that time that Allan invited me to contribute to the Balme Festschrift and to co-edit Philosophical Issues in Aristotle's Biology; and of course, I attended all the workshops and conferences in which Allan was involved in the 1980s and 1990s. We completed the editing of PIAB (as we came to call it) in the Spring of 1987, while I was a Fellow at Clare Hall-in fact, Allan, my daughter, and I resided together in an apartment that backed on Fenner's Lawn, the Cricket Pitch in Cambridge. During those years Allan introduced me to Pen-y-Guryd. One such visit, in 1985, occurred during a tour of Wales with Allan and Cynthia Freeland. Our next joint venture in Great Britain was in 1994 when, at the invitation of David Charles, Allan and 
I co-taught a graduate seminar with Charles at Oxford, once more under the title 'Philosophical Issues in Aristotle's Biology'.

It was during these years of working intensely with Allan on many different projects that I came to appreciate one of his defining character traits-his ability to keep large, long range goals in view while simultaneously focusing with great intensity on every detail that was necessary to achieving those goals. This aspect of his character was a constant, whether he was working on a philosophical problem, doing historical research, planning a seminar, editing a paper or book for publication, or planning a trip. I sometimes found working on projects with him exhausting but in the end always wonderfully rewarding.

In 2002, while the founder and then director of the Anthem Foundation, John McCaskey, was visiting in the Department of History and Philosophy of Science in Pittsburgh and working on a dissertation on the history of induction at Stanford, we discussed the idea of creating a fellowship for Allan to be held in my department at the University of Pittsburgh. As a result, from 2003-2012, Allan was a Visiting Professor of HPS and Anthem Fellow for the Study of Objectivism. As noted above, this gave Allan and me the opportunity to collaborate in a variety of ways. A wonderful case of Aristotelian $\tau$ хй occurred when one of Allan's best undergraduates during his last years at TCNJ, Greg Salmieri, was accepted into graduate school by Pittsburgh's Philosophy Department in 2001 and Allan became an Anthem Fellow at the University of Pittsburgh in 2003. Thanks to his Fellowship, Allan and I thus shared the unexpected pleasure of serving on Salmieri's dissertation committee.

At some point our relationship evolved from Allan being a teacher and mentor to a colleague and friend and, as I liked to say, co-conspirator. What never changed was Allan's benevolent spirit, which showed itself in many ways both great and small, from the many ways in which he encouraged and supported my work professionally to the unexpected postcards or gifts that would arrive in the mail.

The only other person with whom I have had as close and continuous a relationship is the person to whom I am married. The loss of someone who has been a close friend for most of your adult life creates a void that cannot be filled, of course. In a very real sense, however, Allan is still here-in his publications, in his lasting impact on our profession, in the memories of his 
friends and colleagues, and through the inspirational influence on students during more than four decades of teaching. 